\title{
A COMPARATIVE STUDY OF RESPIRATORY PROBLEMS BETWEEN THE RICE MILL EMPLOYEES AND THEIR CONTROLS WORKING IN MAHABOOBNAGAR TOWN, TELANGANA STATE
}

\author{
Chintamala Koteswaramma ${ }^{1}$
}

${ }^{1}$ Associate Professor \& HOD, Department of Community Medicine, Rajeevgandhi Institute of Medical Sciences, Adilabad, Telangana State.

ABSTRACT
BACKGROUND
Agricultural respiratory diseases are also an important public health problem and the affected population is large one and the
respiratory diseases due to exposure to rice mill dust are at least in theory preventable globally. The aims of this study is to
estimate and compare the pattern of respiratory problems including their socio-demographic and environmental factors between
the rice mill employees and their controls who are working in Mahaboobnagar town, Telangana.

\section{MATERIALS AND METHODS}

It was a cross-sectional and comparative study done over a period of 6 months from September 2015 to March 2016 among the workers of 4 rice mills with simple random sampling technique which were located in Mahaboobnagar town. We conducted our study in a convenient sample population, as it was a pilot project with constrained resources where exposure and control group was 1:1 (100 each) ratio. The study tool (questionnaire) was taken from the textbook of "Occupational lung diseases by Fishman and ----"[15] Eligibility criteria of study population: (1). Exposure group was the employees of 4 selected rice mills and Control group was selected from the 4 government offices of Mahaboobnagar town who were present on the day of the study and given the informed consent to participate in the study. The principal investigator was the author (Associate Professor) and trained house surgeons. Data analysis: Data was double checked for any error of translation after the entry into Microsoft Excel 2010 and the results were interpreted in the form of rates/ratios and presented as tables, bar charts and pie diagrams. Chi-square test was used to study the strength of association between the different variables.

\section{RESULTS}

More than 80\% of both Exposure and Control population were found in 31 - 50 years' age group and 4\% more males were working in Exposure group than Control group and it was reverse in case of female gender. The difference found in the prevalence of respiratory morbidity was statistically significant $(48.38 \%)$ between Exposure and Control groups $(\mathrm{P}<0.0000045$, Odds ratio= 4.47). Those who have both rice dust and tobacco smoke exposure were having significantly high (23.02\%) respiratory morbidity than those without rice dust exposure of total study prevalence $(\mathrm{P}<0.0046$, Odds ratio $=2.70)$. The present study shows that the prevalence of respiratory morbidity was high among the employees who were involved in sweeping and cleaning the rice mill (93.75\%) followed by people dealing with the husk and milling other products (filling and packing, etc.) with $69.23 \%$ and filling the bags with rice grains with $50 \%$ and was among other works. Study observed that as the duration of exposure to rice dust was increasing, the severity and prevalence of the respiratory symptoms was also increasing $(\mathrm{P}<0.0014$, Odds ratio= 16.50).

\section{CONCLUSION}

The prevalence of respiratory morbidity was significantly high among economically more productive age group (31 - 50 years), males and smokers with rice dust exposure and among those who clean and sweep the floor of the rice mills, and as duration of exposure increases the severity of the respiratory morbidity also increases. Thus, we strongly recommend that every rice mill management should adopt the dust control and personal protective measures strictly including periodic health examinations to their employees, otherwise license to run that mill must be cancelled by the government.

\section{KEYWORDS}

Respiratory Morbidity, Hazardous Rice Dust, Paddy, Milling, Occupational Exposure, Duration of Exposure, Economic Status and Literacy Level.

HOW TO CITE THIS ARTICLE: Koteswaramma C. A comparative study of respiratory problems between the rice mill employees and their controls working in Mahaboobnagar town, Telangana state. J. Evolution Med. Dent. Sci. 2017;6(58):4297-4302, DOI: $10.14260 /$ Jemds/2017/929

Financial or Other, Competing Interest: None.

Submission 23-02-2017, Peer Review 08-07-2017,

Acceptance 15-07-2017, Published 20-07-2017.

Corresponding Author:

Dr. Chintamala Koteswaramma,

H. No. 7102, Block No.7,

Meerpet, Near Balapur X-Road,

Saroornagar Mandal-500097,

Rangareddy District, Telangana State.

E-mail: chkoti.eshwari@gmail.com

DOI: $10.14260 /$ jemds $/ 2017 / 929$

\section{BACKGROUND}

Agriculture related respiratory diseases are one of the first recognised occupational hazards. Olaus Magnus (1555) warned about the dangers of rice grain dust and the risk was again noted in 1700 by Ramazzini in his seminal work De Morbis Artificum.[1],[2] Despite this early recognition, it has only been in $20^{\text {th }}$ century that this problem has been carefully studied and documented. The effects of air pollutants on lungs have been renewed by Bates (1972). According to him inhaled particles or gases may produce their effect at 3 different sites- major airways, small airways and the 
alveoli.[3] Over a period of time there may be paralysis of cilia, hypertension and hypertrophy of bronchial mucous glands in terminal bronchioles and alveoli. The pathogenesis of asthma induced or exacerbated by exposures in rice mill settings is highly voluble and entirely dependent on the specific nature and intensity of exposure. Recurrent episodes of allergic and non-allergic inflammation may result in chronic remodelling of the conducting airways and may lead to development of progressive airflow obstruction. ${ }^{[4]}$

Damage to the lungs by dust, fumes or noxious substances inhaled by workers of certain specific occupations is known as occupational lung disease.[5] "Respirable Dust" is a term loosely applied to solid particles ( $<20$ microns) and capable of temporary suspension in air or other gases. Derivation from larger masses through the application of physical force is usually implied.[5] The term "pneumoconiosis" was redefined by IV industrial conference of experts (ILO) in 1971 as "accumulation of dust in lungs and tissue reactions due to its presence" in agricultural work environment holds the potential for exposure to many agents that may cause respiratory diseases.[6],[7]

So far many hundred millions of people worldwide are exposed to hazardous dusts in course of their work in agriculture, extractive industries, rice mills, food processing, etc. And these are preventable if workers use protective measures during the process of grain lifting, milling, drying, emptying the bags dropping from hoofer to weight stations etc., where large amount of dust is released into the environment of the mill (Pdurst and Dosman, 1990). Thus, workers are potentially exposed to rice mill dust which is a heterogeneous substance $(<20$ microns) that contains a number of contaminants including silica, fungi, bacterial endotoxins, aflatoxins, mammalian debris and certain chemical additives such as pesticides and herbicides. This environmental dust is a hazardous substance with respiratory sensitivity and workers exposed have been reported to exhibit a variety of chemical manifestations like allergic rhinitis, cold, cough, tightness in the chest, difficulty in breathing, periodic cough and phlegm, etc.[3] Around $58.45 \%$ of the Indian population mainly depends on agriculture for their livelihood.[8],[9] India is the second biggest rice producing country.[10]

However, relatively few epidemiologic data are available addressing pulmonary infections on context of the agricultural work environment in Telangana state. So it is beyond the scope to have data on rice mills (dust) associated respiratory problems. Thus, we started a study at Mahaboobnagar district which is socioeconomically a backward district of Telangana state where most of the land is used for agricultural purposes. In town, it has 14 rice mills and most of them carry out rice milling on crude machinery emitting large amount of rice dust into the environment. We studied the pattern, prevalence of respiratory problems and tried to compare the same with the control group.

\section{MATERIALS AND METHODS}

- Study Universe: Mahaboobnagar is a town and a municipal corporation is located at a distance of $96 \mathrm{~km}$ from Hyderabad. City is bordered with River Krishna in the south and surrounded by Nalgonda, Hyderabad, Kurnool, Raichur and Gulbarga districts. As per
2011 Census of India, the district has a population of 1,318,110.[11]

- Study Setting: Procedure of selection: First we prepared the list of all 26 registered rice mills working in Mahaboobnagar town, then we selected 4 rice mills from the list by simple random sampling technique (with ten rupee note). They are- 1). Raghavendra rice mill, 2) Srinivasa rice mill, 3). Venkateswara rice mill and 4) Anjaneya rice mill.[12]

- Study Design and Period: A cross-sectional, comparative study done over a period of 6 months from September 2015 to March 2016.

- Sample Size: As the study was a pilot project with constrained resources (time and money), we took both 100 samples for each Exposure and Control group in 1:1 ratio and selection of the sample population was done in a convenient sample method. We took 25 exposed subjects from each rice mill $(25 \times 4=100)$ and control (non-exposure) subjects of 100 from the government offices of that town.

- Study Tool (Questionnaire): It was taken from the textbook of "Occupational lung diseases by Fishman and --- which was pretested in Indian population by Seema Prakash, Manjulatha et al.

- Study Population: i. Exposure group (case): It was the employees working in rice mills of Mahaboobnagar town, who gave the informed consent to participate in the study and present on the day of the study from which we collected the required data by using the study tool at the rice mills itself by conducting a medical camp. About 25 employees were interviewed over a period of 5 days in each rice mill, thus total $100(5 \times 5$ days $\times 4$ rice mills = 100) were interviewed. ii. Control group: This population was selected from the 4 government offices named Electricity and Telephone, Waterworks Department and Collector office. From each office we have selected 25 employees working at various positions (Managers, UDC, LDC and sweepers, etc.) who gave consent and present on the day of examination.

- Investigators of the Study: The principal investigator (Associate professor, the author) and trained internees.

- Data Analysis and Presentation: Data was double checked for any error of translation after the entry into Microsoft Excel 2010 sheet and the results were analysed and interpreted in the form of rates/ratios and presented as tables, bar charts and pie diagrams. And chi-square test and odds ratio were done by Epi-Info 3.54 software to study the significance of association between the different variables.

\section{DISCUSSION}

The present cross-sectional and comparative study was undertaken on four rice mill employees of Mahaboobnagar town of Telangana state for a period of 6 months from September 2015 to March 2016 and the present study results were- The data was collected and analysed for a total of 200 subjects, i.e. 100 from each exposure and control group. The study has shown that a significantly high proportion of exposure and control subjects (82\% and $80 \%$, respectively) were falling in 31 - 50 years than other ages with Chi-square test value of $5.914, \mathrm{p}<0.015$ at $95 \%$ confidence interval, $\mathrm{df}=$ 
2 and Odds ratio $=0.42$, on whom most of the families are usually dependent upon socially and economically (Table No. 1) and if this age group is affected by ill health then the whole family will be affected. So, caring for these people's health is very crucial in maintaining the community health.

We also observed that among exposure group males were $4 \%$ more than the control group $(62 \%$ and $58 \%$, respectively) and it was reverse in case of females (38\% and $42 \%$, respectively). It may be because of $30 \%$ reservation for ladies in government offices.

The study shows that $74 \%$ exposed subjects belonged to lower socioeconomic class. But it was $14 \%$ lower in control group than exposure group. And the illiteracy rate was $36 \%$ high among the exposure group than the control group. And in case of Graduation and above qualification, it was $10 \%$ higher among control group than exposure group $(4 \%$ and $14 \%$, respectively).

\section{RESULTS}

\begin{tabular}{|c|c|c|c|}
\hline $\begin{array}{l}\text { Cooking } \\
\text { Fuel }\end{array}$ & $\begin{array}{c}\text { Exposure } \\
\text { Group }\end{array}$ & $\begin{array}{l}\text { Control } \\
\text { Group }\end{array}$ & Total \\
\hline $\begin{array}{c}\text { Gas } \\
\text { stove/electric } \\
\text { stove }\end{array}$ & $\begin{array}{c}40(33.33 \%) \\
(40.00 \%)\end{array}$ & $\begin{array}{c}80 \\
(66.67 \%) \\
(80.00 \%)\end{array}$ & $\begin{array}{c}120 \\
(100 \%) \\
(60.00 \%)\end{array}$ \\
\hline $\begin{array}{l}\text { Kerosene } \\
\text { stove }\end{array}$ & $\begin{array}{c}20(52.94 \%) \\
(20.00 \%)\end{array}$ & $\begin{array}{c}5 \\
(47.06 \%) \\
(5.00 \%)\end{array}$ & $\begin{array}{c}25 \\
(100 \%) \\
(12.50 \%)\end{array}$ \\
\hline $\begin{array}{l}\text { Fire wood } \\
\text { and coal }\end{array}$ & $\begin{array}{c}27(84.38 \%) \\
(27.00 \%)\end{array}$ & $\begin{array}{c}5 \\
(15.62 \%) \\
(5.00 \%) \\
\end{array}$ & $\begin{array}{c}32 \\
(100 \%) \\
(49.00 \%) \\
\end{array}$ \\
\hline Others* & $\begin{array}{c}13(56.52 \%) \\
(13.00 \%)\end{array}$ & $\begin{array}{c}10 \\
(43.48 \%) \\
(34.00 \%)\end{array}$ & $\begin{array}{c}23 \\
(100 \%) \\
(11.50 \%)\end{array}$ \\
\hline Total & $\begin{array}{c}100(50 \%) \\
(100 \%)\end{array}$ & $\begin{array}{c}100 \\
(50 \%) \\
(100 \%)\end{array}$ & $\begin{array}{c}200 \\
(100 \%) \\
(100 \%)\end{array}$ \\
\hline
\end{tabular}

Chi-square test value $=37.85, \mathrm{P}<0.00000003$ at $95 \%$ confidence interval, $\mathrm{df}=3$, *electric stove, solar stove, etc.

Table No. 1 is showing that $47 \%$ of the exposure group was using kerosene, firewood and coal as cooking fuel, whereas it was only $10 \%$ among control group. That means the exposure group was having $37 \%$ more risk of getting smoke exposure than the control group.

\begin{tabular}{|c|c|c|c|}
\hline $\begin{array}{c}\text { Kitchen } \\
\text { Present in } \\
\text { Living Room }\end{array}$ & $\begin{array}{l}\text { Exposure } \\
\text { Group }\end{array}$ & $\begin{array}{l}\text { Control } \\
\text { Group }\end{array}$ & Total \\
\hline $\begin{array}{l}\text { Kitchen with } \\
\text { vent }(n=)\end{array}$ & $\begin{array}{c}29(90.62 \%) \\
(36.71 \%)\end{array}$ & $\begin{array}{c}8(13.80 \%) \\
(72.72 \%)\end{array}$ & $\begin{array}{c}37(100 \%) \\
(41.11 \%)\end{array}$ \\
\hline $\begin{array}{l}\text { Kitchen without } \\
\text { vent }(n=)\end{array}$ & $\begin{array}{c}50(86.20 \%) \\
(63.29 \%)\end{array}$ & $\begin{array}{l}3(9.28 \%) \\
(27.28 \%)\end{array}$ & $\begin{array}{c}53(100 \%) \\
(58.59 \%)\end{array}$ \\
\hline Total & $\begin{array}{c}79(87.78 \%) \\
(100 \%\end{array}$ & $\begin{array}{c}11(12.22 \%) \\
(100 \%)\end{array}$ & $\begin{array}{c}90(100 \%) \\
(100 \%)\end{array}$ \\
\hline \multicolumn{4}{|c|}{$\begin{array}{c}\text { Table 2. Distribution of Exposure and Control Groups as } \\
\text { per Presence of Kitchen in Living } \\
\text { Room and Presence of Vent }\end{array}$} \\
\hline
\end{tabular}

Table No. 2, about $75.65 \%$ more number of exposed subjects were not having separate kitchen in their residence than the control group. And kitchen without vent was $36.01 \%$, high among exposed group than the control group. This means exposure group was having more than 2 times risk of getting exposed to kitchen fumes, vapours, gases and smoke in addition to the rice dust.

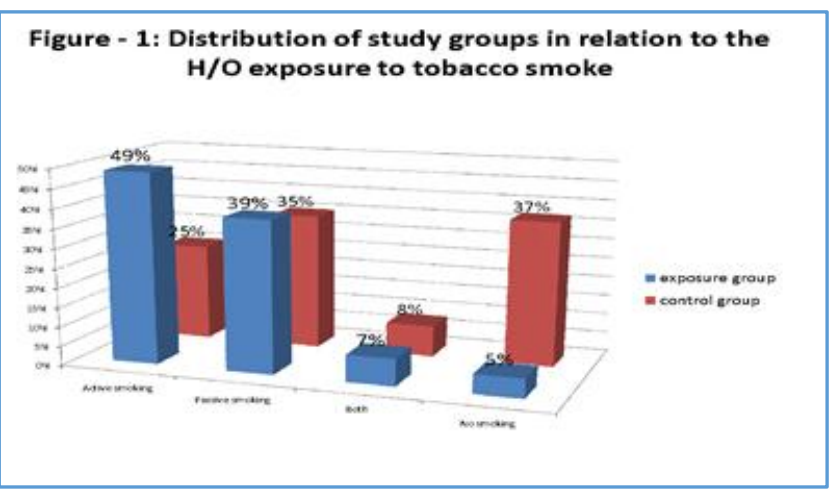

Figure No. 1, revealing that about $60 \%$ and $25 \%$ of the exposure and control group respectively was found to have only smoking habit (Smoking at least three cigarettes/day). And $19 \%$ of the exposure group and $30 \%$ of the control group was found to have $\mathrm{H} / \mathrm{O}$ of passive smoking (exposure for more than two hours/day), whereas about $7 \%$ and $8 \%$ of the exposure and control groups were having both active and passive smoking, but $5 \%$ and $37 \%$ of the exposure and control groups did not have the exposure to tobacco smoke respectively. About $18 \%$ of the exposure group and $20 \%$ of the control group were found to have $\mathrm{H} / \mathrm{O}$ of passive smoking among the total study population.

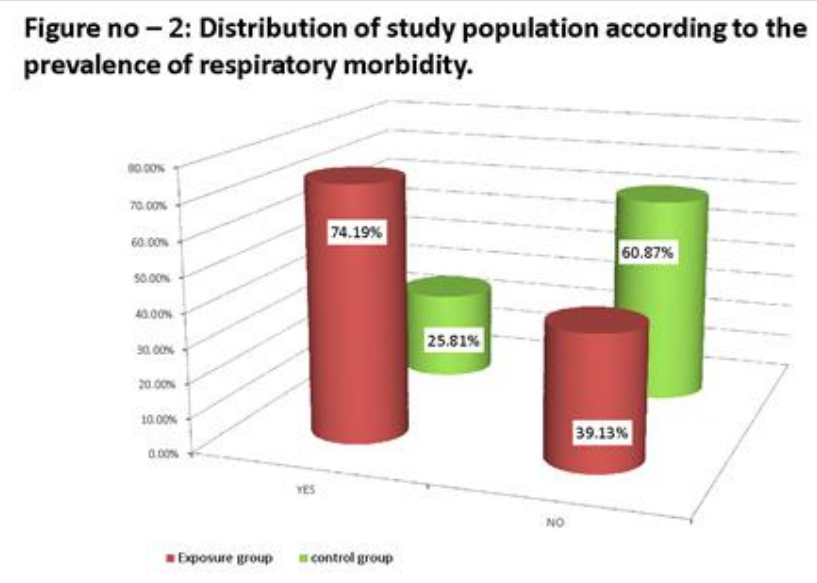

Figure No. 2 was showing that about $74.19 \%$ and $39.13 \%$ of the exposure and control group were suffering from the respiratory morbidity out of total prevalence of study population. This observed difference was statistically significant $\left(\mathrm{X}^{2}=21.04, \mathrm{P}<0.0000045\right.$ at $95 \%$ confidence interval) and Odds ratio $=4.47$. This means, within the exposed group, the respiratory morbidity was 4.43 times higher than the control group. 


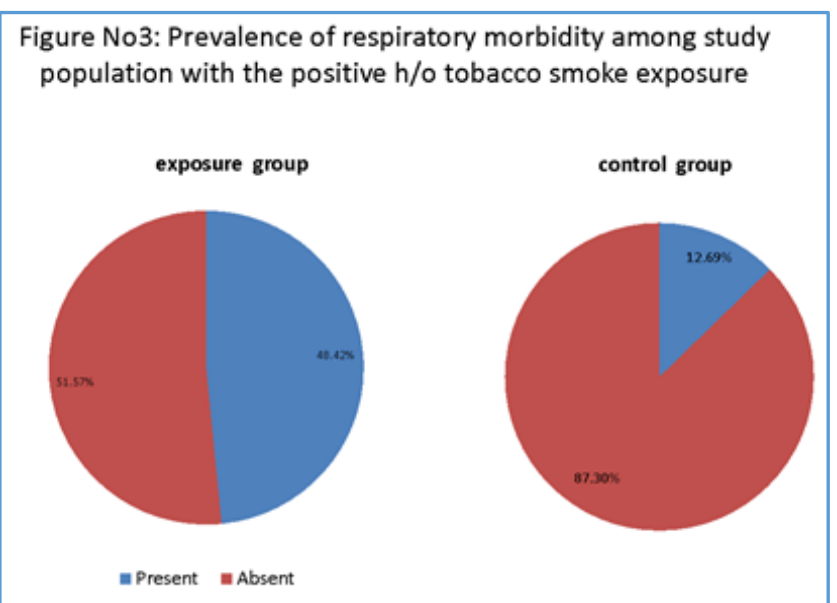

Figure No. 3 is showing that out of total prevalence of respiratory morbidity among those who have both the rice dust and tobacco smoke exposure contributing to $48.42 \%$ and those who do not have rice dust exposure but have tobacco smoke exposure in various ways were showing about $25.40 \%$. This observed difference in prevalence of respiratory morbidity among exposure group to control group was statistically significant (chi-square test value $=$ 8.02, $\mathrm{P}<0.0046$ at $95 \%$ confidence interval) and Odds ratio $=$ 2.70. Thus, workers who smoke are at a 5 times greater risk of having the lung disease if they are exposed to rice dust; similar results were mentioned by American Academy of Family Physicians Publication named "Occupational Respiratory Diseases."

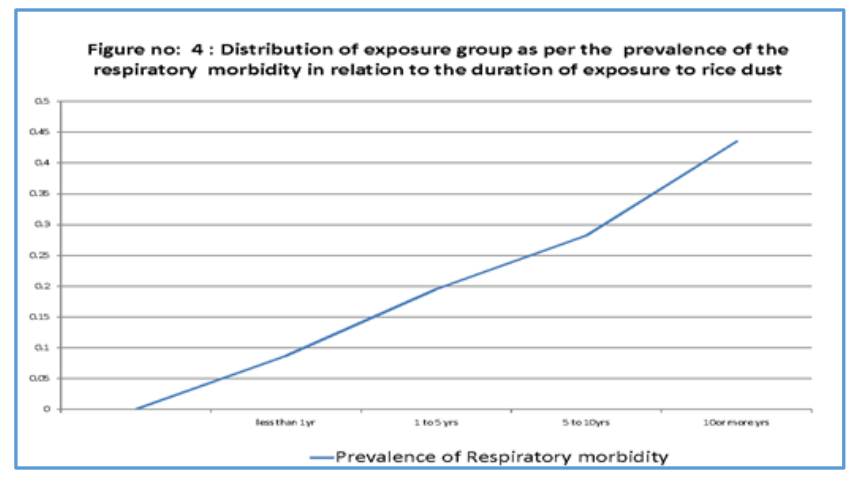

Figure No. 4 was showing that the prevalence of respiratory morbidity was proportionately increasing with the duration of exposure to rice dust.

\begin{tabular}{|c|c|c|c|}
\hline \multirow{2}{*}{$\begin{array}{c}\text { Study } \\
\text { Population }\end{array}$} & \multicolumn{3}{|c|}{ Respiratory Morbidity } \\
\hline & $\begin{array}{c}\text { Mild } \\
\text { Form* }\end{array}$ & $\begin{array}{c}\text { Severe } \\
\text { Form** }\end{array}$ & \\
\hline Exposure group & $\begin{array}{c}9 \\
(19.56 \%)\end{array}$ & $\begin{array}{c}37 \\
(80.44 \%)\end{array}$ & $\begin{array}{c}46 \\
(100 \%) \\
(74.20 \%)\end{array}$ \\
\hline Control group & $\begin{array}{c}12 \\
(75 \%)\end{array}$ & $\begin{array}{c}4 \\
(25 \%)\end{array}$ & $\begin{array}{c}16 \\
(100 \%) \\
(25.80 \%)\end{array}$ \\
\hline Total & $\begin{array}{c}21 \\
(33.87 \%) \\
(100 \%)\end{array}$ & $\begin{array}{c}41(66.12 \%) \\
(100 \%)\end{array}$ & $\begin{array}{c}62 \\
(100 \%) \\
(100 \%)\end{array}$ \\
\hline
\end{tabular}

*Mild symptoms: Nasal catarrh, irritant cough with or without expectoration less than 2 months and shortness of breath on exertion. ${ }^{* *}$ Severe symptoms: Chronic morning cough with or without expectoration or blood, shortness of breath on rest, chronic asthma (after start of the occupation) and Chronic Obstructive Pulmonary Disease (COPD). $\left(\mathrm{X}^{2}=16.29, \mathrm{P}<0.0000544\right.$ at $95 \%$ confidence interval and Odds ratio $=0.08$ ).

Table No. 3 has shown that about $80.44 \%$ and $25 \%$ of the respiratory morbidity was of severe form among exposure and control groups respectively out of their total respiratory morbidity and rest was the mild form. This difference was significant $\left(\mathrm{X}^{2}=16.29, \mathrm{P}<0.0000544\right.$ at $95 \%$ confidence interval and Odds ratio $=0.08$ ).

\begin{tabular}{|c|c|c|c|}
\hline $\begin{array}{c}\text { Duration of } \\
\text { Exposure to } \\
\text { Rice Dust } \\
\text { (In Years) }\end{array}$ & $\begin{array}{c}\text { Respiratory Symptoms in } \\
\text { Exposure Group }\end{array}$ & \multirow{2}{*}{ Total } \\
\cline { 2 - 3 } & Mild * & Severe ** & \\
\hline$<1$ & $2(4.34 \%)$ & $0(\%)$ & $2(4.34 \%)$ \\
\hline $1-5$ & $4(8.6 .8 \%)$ & $4(8.6 .8 \%)$ & $8(17.39 \%)$ \\
\hline $5-10$ & $2(4.34 \%)$ & $12(26.08 \%$ & $16(34.78 \%)$ \\
\hline$>10$ yrs. & $1(2.17 \%)$ & $21(45.65 \%)$ & $22(47.82 \%)$ \\
\hline Total & $\begin{array}{c}9(19.56 \%) \\
(100 \%)\end{array}$ & $\begin{array}{c}37(80.44 \%) \\
(100 \%)\end{array}$ & $\begin{array}{c}46(100 \%) \\
(100 \%)\end{array}$ \\
\hline \multirow{2}{*}{$\begin{array}{c}\text { Table 4. Distribution of various Respiratory Morbidities } \\
\text { in Relation to the Duration of Exposure to Rice Dust }\end{array}$} \\
\hline
\end{tabular}

(Chi-square test value $=10.28, \mathrm{P}<0.0014$ at $95 \%$ confidence interval, Odds ratio $=16.50$ ).

Table No. 4 has shown that as the duration of exposure to rice dust was increasing, the severity and prevalence of the respiratory symptoms was also increasing significantly with $\mathrm{p}<0.0014$ and it also showed that Odds ratio $=16.50$, means the respiratory morbidity was 16.50 times higher among the exposed group for $\geq 5$ years than $<5$ years of exposure.

\begin{tabular}{|c|c|c|c|}
\hline \multirow{2}{*}{$\begin{array}{l}\text { Site of Working } \\
\text { (Exposure Group) }\end{array}$} & \multicolumn{2}{|c|}{ Respiratory Illness } & \multirow[b]{2}{*}{ Total } \\
\hline & $\begin{array}{c}\text { Present } \\
(n=46)\end{array}$ & $\begin{array}{l}\text { Absent } \\
(n=54)\end{array}$ & \\
\hline $\begin{array}{l}\text { Pouring the grains into } \\
\text { the grinding machine }\end{array}$ & $2(25 \%)$ & $6(75 \%)$ & $\begin{array}{c}8 \\
(100 \%)\end{array}$ \\
\hline Loading and Unloading & $\begin{array}{c}2 \\
(15.38 \%) \\
\end{array}$ & $\begin{array}{c}11 \\
(84.61 \%) \\
\end{array}$ & $\begin{array}{c}13 \\
(100 \%)\end{array}$ \\
\hline Sweeping and cleaning & $\begin{array}{c}15 \\
(93.75 \%) \\
\end{array}$ & $\begin{array}{c}1 \\
(6.25 \%) \\
\end{array}$ & $\begin{array}{c}16 \\
(100 \%) \\
\end{array}$ \\
\hline $\begin{array}{l}\text { Filling of the bags with } \\
\text { rice grains }\end{array}$ & $6(50 \%)$ & $6(50 \%)$ & $\begin{array}{c}12 \\
(100 \%)\end{array}$ \\
\hline Packing and branding & $\begin{array}{c}4 \\
(28.57 \%) \\
\end{array}$ & $\begin{array}{c}10 \\
(71.48 \%) \\
\end{array}$ & $\begin{array}{c}14 \\
(100 \%) \\
\end{array}$ \\
\hline $\begin{array}{c}\text { Dealing with the husk } \\
\text { and other products } \\
\text { (filling and packing, } \\
\text { etc.) }\end{array}$ & $\begin{array}{c}9 \\
(69.23 \%)\end{array}$ & $\begin{array}{c}4 \\
(30.77 \%)\end{array}$ & $\begin{array}{c}13 \\
(100 \%)\end{array}$ \\
\hline $\begin{array}{l}\text { Boiler and Mill machine } \\
\text { operator }\end{array}$ & $\begin{array}{c}6 \\
(42.85 \%) \\
\end{array}$ & $\begin{array}{c}8 \\
(57.15 \%) \\
\end{array}$ & $\begin{array}{c}14 \\
(100 \%) \\
\end{array}$ \\
\hline Manager/Supervisors & $2(20 \%)$ & $8(80 \%)$ & $\begin{array}{c}10 \\
(100 \%) \\
\end{array}$ \\
\hline Total & $\begin{array}{c}46 \\
(46 \%)\end{array}$ & $\begin{array}{c}54 \\
(54 \%)\end{array}$ & $\begin{array}{c}100 \\
(100 \%)\end{array}$ \\
\hline Table 5. Distribu & & & \\
\hline
\end{tabular}

The present study shows that the prevalence of respiratory morbidity was high among the employees who 
were involved in sweeping and cleaning the rice mill (93.75\%) followed by people dealing with the husk and milling other products (filling and packing, etc.) with 69.23\% and filling the bags with rice grains with $50 \%$ and was among other works (Table No. 5). This difference was significant $\left(\mathrm{X}^{2}\right.$ test $=28.40, \mathrm{P}<0.00018$ at $95 \%$ confidence interval and $\mathrm{df}=$ 7).

\section{CONCLUSION}

1. A significantly high proportion of exposure and control subjects ( $82 \%$ and $80 \%$, respectively) were falling in 31 50 years than other ages with $\mathrm{P}<0.015$, on whom family members were usually dependent upon socially and economically. And if this age group is affected by ill health, then whole family will be affected.

2. Among exposure group males were $4 \%$ more than the control group and it was reverse in case of females. It may be because of $30 \%$ reservation for ladies in government offices.

3. Percentage of lower socioeconomic class was $14 \%$ lower in case of control group than exposure group. It was because government employees have regular income, reimbursement of healthcare and education services.

4. Illiteracy rate was $36 \%$ higher among the exposure group than the control group. And in case of Graduation and above qualification, it was $10 \%$ higher among control group than exposure group.

5. About $47 \%$ of the exposure group was using kerosene, firewood and coal as cooking fuel, whereas it was only $10 \%$ among control group. That means the exposure group was having $37 \%$ more risk of getting smoke exposure than the control group.

6. The risk of getting exposed to kitchen fumes, vapours, gases and smoke in addition to the rice dust was more than 2 times high among exposure group than the control group, because $75.65 \%$ of them were not having separate kitchen and $36.01 \%$ of them were not having kitchen.

7. The exposure and control groups found with smoking habit was $60 \%$ and $46 \%$ respectively. And $19 \%$ and $30 \%$ of the exposure and control groups were having the $\mathrm{H} / \mathrm{O}$ of passive smoking. And active and passive smoking was seen among $7 \%$ and $8 \%$ of the exposure and control groups, respectively.

8. There was a significant difference in the prevalence of respiratory morbidity $\left(\mathrm{X}^{2}=21.04, \mathrm{P}<0.0000045\right.$, Odds ratio $=4.47$ ) among exposure and control groups (74.19\% and $25.81 \%$, respectively).

9. The observed difference in prevalence of respiratory morbidity in relation to the tobacco smoke among exposure and control groups was statistically significant (48.42\% and $25.40 \%$, respectively) with $\mathrm{X}^{2}=8.02, \mathrm{P}<$ 0.0046 and Odds ratio $=2.70$.

10. The prevalence of respiratory morbidity was proportionately increasing with the duration of exposure to rice dust.

11. The prevalence of respiratory morbidity was high among the employees who were involved in sweeping and cleaning the rice mill (93.75\%) followed by people dealing with the husk and milling other products (filling and packing, etc.) with $69.23 \%$ and filling the bags with rice grains with $50 \%$ and was among other works.
12. Severe form of respiratory morbidity seen among exposure and control groups was about $80.44 \%$ and $25 \%$ respectively out of their total respiratory morbidity. This difference was significant $\left(\mathrm{X}^{2}=16.29, \mathrm{P}<\right.$ 0.0000544 at $95 \%$ confidence interval and Odds ratio $=$ $0.08)$.

13. The study has shown that as the duration of exposure to rice dust was increasing, the severity and prevalence of the respiratory symptoms was also increasing $\left(\mathrm{X}^{2}=\right.$ $10.28, \mathrm{P}<0.0014$ at $95 \%$ confidence interval and Odds ratio $=16.50$ )

\section{Recommendations}

1. To initiate personal protective measures to all who were involved in rice mill work.

2. To take care of dust reduction measures in the mill environment by proper ventilator systems.

3. To clean the floor of the mill only after wetting it, otherwise dust will spread in the air and increases the risk of exposure to rice dust in many folds.

4. There should be regular medical screening for the employees of the rice mill on quarterly basis and the employees who were having cough for more than 2 weeks should be counselled to go for sputum test for mycobacterium tuberculosis.

5. Health education to the rice mill employers and employees must be done about the dangers of rice dust exposure, their symptom and also available preventive measures from rice dust exposure.

\section{Limitations of the Study}

The study was limited to only single town and the sample taken was a convenient sample because of resource constrained including time. Thus, the drawn results from this study cannot be extrapolated with the whole population (Universe of rice mill workers), as the convenient sampling will affect the external validity of the study. Thus, we need to do extensive study to confirm our results.

\section{REFERENCES}

[1] Respiratory health hazards in agriculture. American Journal of Respiratory and Critical Care Medicine 1998;158(5 Pt 2):S1-S76.

[2] World Health Organization. Occupational health problems in agriculture: fourth report of the joint ILO/WHO Committee on occupational health. WHO, Geneva 1962.

[3] Bates DV. Air pollutants and the human lung. American review of Respiratory diseases 1972;105(1).

[4] Bates DV. The fate of chronic bronchitic: a report of ten year follow up in the Canadian department of veteran's affairs co-ordinated study of chronic bronchitis. American Review of Respiratory Diseases 1973;108(5):1043-65.

[5] Cote J, Kennedy S, Chan-Yeung M. Outcome of patients with cedar asthma with continuous exposure. Am Rev Respir Dis 1990;141(2):373-6.

[6] Dinman BD, Jonathan D. The Mode of Absorption, Distribution, and Elimination of Toxic Materials. Wiley online Library 2001. 
[7] O'Neill CH, Hodges GM, Riddle PN, et al. A fine fibrous silica contaminant of flour in the high oesophageal cancer area of north-east Iran. Int J Cancer 1980;26(5):617-28.

[8] Prakash S, Manjunatha S, Shashikala C. Morbidity patterns among rice mill workers: a cross sectional study. Indian J Occup Environ Med 2010;14(3):91-3.

[9] Nayak P. Problems and prospects of rice mill modernization: a case study. J Assam University 1996;1:22-8.
[10] Musa R, Naing L, Ahmad Z, et al. Respiratory health of rice millers in Kelantan, Malaysia. Southeast Asian J Trop Med and Public Health 2000;31(3):575-8.

[11] Ye TT, Huang JX, Shen YE, et al. Respiratory symptoms and pulmonary functions among Chinese rice granary workers. Int J Occup Environ Health 1998;4(3):155-9.

[12] Mahaboobnagar.nic.in, companies list, Dt: 22.02.2017. http://en.wikepedia.org/wiki/Mahaboobnagardist: 2017. 